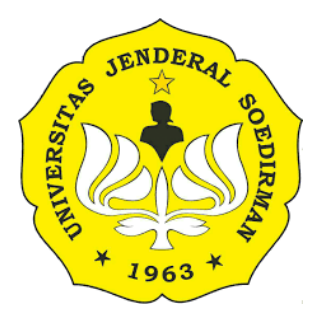

SOEDIRMAN ECONOMICS EDUCATION JOURNAL http://jos.unsoed.ac.id/index.php/seej/

\title{
PENGARUH KUALITAS PENGANGGARAN DAN KOMPETENSI SUMBER DAYA MANUSIA BIDANG KEUANGAN TERHADAP KINERJA KEUANGAN SEKOLAH
}

\author{
Slamet Fauzan \\ Jurusan Akuntansi Fakultas Ekonomi, Universitas Negeri Malang, Indonesia \\ Email corresponding author: slamet.fauzan.fe@um.ac.id
}

\begin{abstract}
Abstrak
Penelitian ini bertujuan untuk mengetahui bagaimana pengaruh kualitas penganggaran dan kompetensi sumber daya manusia bidang keuangan terhadap kinerja keuangan sekolah. Penelitian ini adalah penelitian populasi. Jumlah populasi dalam penelitian ini adalah seluruh sekolah menengah kejuruan (SMK) di Kabupaten Pemalang dengan jumlah 42 sekolah. Dalam penelitian ini, jumlah SMK yang mengembalikan kuisonernya sebanyak 32 SMK. Pendekatan penelitian ini menggunakan metode kuantitatif dengan desain penelitian hypothesis testing study. Uji hipotesis menggunakan uji regresi linier berganda. Berdasarkan hasil penelitian ini, menunjukkan bahwa kualitas penganggaran dan kompetensi sumber daya manusia bidang keuangan secara simultan maupun parsial berpengaruh signifikan positif terhadap kinerja keuangan sekolah. Semakin baik kualitas penganggaran dan sumberdaya manusia bidang keuangan maka akanmeningkatkan kinerja keuangan sekolah.
\end{abstract}

Kata Kunci : Kualitas penganggaran, kompetensi sumber daya manusia bidang keuangan, kinerja keuangan

\begin{abstract}
This research was conducted to identity the influence of budget quality and financial human resources competence on the school financial performance.. This research is population research. The number of population in this research is among all the vocational haigh school in Pemalang Regency with totaling 42 schools. In this study, the number of SMK that returned the questionnaire was 32 SMK. This research approach uses quantitative methods with the research design hypothesis testing study. Hypothesis testing using multiple linear regression test. Based on the results of this study, it shows that the quality of budgeting and the competence of human resources in finance simultaneously and partially have a significant positive effect on school financial performance. The better the quality of budgeting and human resources in finance, the better the school's financial performance.
\end{abstract}

Keywords: budget quality, financial human resources competency, school financial performance. 


\section{PENDAHULUAN}

Kinerja keuangan sekolah merupakah faktor penting dalam penentuan kinerja sekolah. Hal ini sejalan dengan pendapat Widodo, (2014) yang mengungkapkan bahwa antara anggaran dan kinerja sekolah tidak dapat dipisahkan baik secara konseptual maupun implementasinya. Apabila dilihat dari segi konseptual tidak dapat dipisahkan karena bersamaan berangkat serta memiliki orientasi untuk mewujudkan akuntabilitas internal sekolah. Sedangkan jika ditinjau dari segi implementatif juga tidak dapat dipisahkan karena untuk mengawal operasional kegiatan dan program sekolah yang dilakukan oleh pihak manajemen sekolah.

Kinerja keuangan sekolah pada hakikatnya adalah gambaran keadaan keuangan pada suatu periode yang dicapai oleh sekolah. Sedangkan tujuan dari laporan keuangan menurut standar akuntansi keuangan dalam bab kerangka dasar dan penyusunan dan penyajian laporan keuangan yaitu untuk menyediakan informasi yang menyangkut posisi keuangan, kinerja serta perubahan posisi keuangan suatu perusahaan yang dipakai oleh para stakeholder dalam mengambil keputusan ekonomi.

Kinerja keuangan di kabupaten Pemalang masih tergolong rendah. Dapat dilihat dalam hal belanja daerah untuk pegawai seperti yang dikutip dalam detiknews (2011), Kabupaten pemalang termasuk dalam kategori rendah nomor dua di Provinsi Jawa Tengah setelah Kabupaten Kebumen. Hal ini diperkuat oleh temuan dari penelitian Ulumudin (2014), menyatakan bahwa Kabupaten Pemalang termasuk dalam pemetaan kuadran terakhir di Karesidenan Pekalongan beserta Kabupaten Brebes dan Tegal dalam hal kinerja keuangan.

Kelemahan kinerja keuangan sekolah di Kabupaten Pemalang dapat terlihat pada tidak adanya ketentuan tentang transparansi pengelolaan anggaran BOS. Menurut Aiptu Slamet Susanto dan Hargo Kusprihanto pada media berita nasional bhayangkara utama mengungkapkan bahwa setelah dilakukan pengamatan dan observasi di satuan pendidikan di temukan fakta dan bukti-bukti yang sangat akurat terkait pengusulan anggaran BOS di Kab Pemalang Tahun Pelajaran 2015/2016. Di antaranya, jumlah peserta didik yang ada di sekolah berbeda dengan jumlah hibah yang diberikan oleh pemerintah dan hampir rata-rata jumlah anggaran hibah melebihi jumlah peserta didik.

Ironisnya, pencapaian kinerja keuangan sekolah di Indonesia masih sangat rendah. Menurut Indonesia corruption watch, dalam lima tahun terakhir korupsi di dunia pendidikan potensial terjadi. Hal itu terlihat dari hasil audit BPK terhadap laporan keuangan Departemen Pendidikan Nasional, pengelolaan dana alokasi khusus (DAK) dan dana bantuan operasional sekolah (BOS). Berdasarkan perhitungan ICW atas audit BPK, ditemukan potensi penyelewengan di Depdiknas. Penyimpangan itu antara lain terjadi pada pengelolaan asset, tidak tepat sasaran, tanpa bukti pertanggungjawaban, pemborosan, dan penyimpangan lainnya.

Padahal petunjuk teknisnya (juknis) pengusulan anggaran BOS oleh satuan pendidikan berdasarkan jumlah peserta didik yang ada di satuan pendidikan tersebut. Dengan demikian dapat disimpulkan markup data peserta didik dalam pengusulan anggaran BOS sengaja dilakukan oleh oknum 
kepala sekolah dengan motivasi untuk mencari kelebihan dan atau memperkaya diri sendiri. Disinyalir dugaan penyalahgunaan ini di lakukan secara pribadi dan atau bersama-sama di lingkungan satuan pendidikan. Kelemahan lain adalah yayasan dikelola secara tidak professional, karena adanya pengangkatan SDM untuk mengelola yayasan hanya dilakukan secara formalitas belaka.

Jika hal ini terus berlanjut, maka akan menyebabkan tujuan dari pendidikan nasional tidak akan terwujud. Oleh karena itu, diperlukan upaya-upaya untuk membangun kinerja keuangan yang baik. Menurut Penrose (1957) dalam teorinya resources-based theory menyatakan bahwa sekolah akan mencapai keunggulan jika memiliki sumber daya yang unggul. Dengan sumber daya yang unggul diharapkan sekolah mampu melakukan strategi yang baik yang pada akhirnya membawa sekolah untuk memiliki keunggulan kompetitif. Oleh karena itu, perlu adanya kompetensi sumber daya manusia pengelola keuangan dan kualitas penganggaran yang baik sehingga dapat meningkatkan kinerja keuangan sekolah kearah yang lebih kondusif untuk menjamin mutu kinerja organisasi tersebut optimal. Sesuai dengan agency theory apabila satu orang atau lebih mempekerjakan orang lain untuk melakukan jasa dan memberi wewenang pengambilan keputusan kepada agent tersebut. Agen dalam hal ini adalah sumber daya manusia bidang keuangan.

Menurut teori partisipasi anggaran (budgeting partisipation theory), penganggaran dalam suatu organisasi harus melibatkan partisipasi anggota dalam menyusun anggaran tersebut supaya tercapai tujuan organisasi. Salah satu tujuan penting dalam organisasi sekolah adalah kinerja keuangan. Hal ini menjelaskan bahwa transparasi mengambil peran penting dalam terbentuknya kualitas kinerja keuangan sekolah. Kualitas penganggaran mempengaruhi kinerja keuangan sekolah. Hal ini sejalan dengan yang dikemukakan oleh Mardiasmo (2002). Selaras dengan penelitian Riawan (2016) yang menunjukan bahwa kualitas suatu penganggaran akan berdampak positif secara signifikan kepada kinerja keuangan daerah. Hal serupa dinyatakan oleh Kenis (1979), Qi (2010), Silva \& Jayamaha (2014) dalam penelitiannya yang menyatakan karakteristik suatu anggaran (perencanaan anggaran, pengendalian anggaran, partisipasi anggaran, kecanggihan anggaran, kejelasan sasaran anggaran, evaluasi anggaran dan kesulitan sasaran anggaran) berpengaruh positif signifikan terhadap kinerja keuangan, dimana semakin baik suatu proses anggaran dalam suatu organisasi maka hal tersebut berdampak terhadap peningkatan kinerja keuangan suatu organisasi.

Kompetensi SDM dalam bidang keuangan dipercaya dapat memengaruhi kinerja keuangan sekolah. Hal ini sejalan dengan hasil penelitian Wati et al. (2014) yang mengungkapkan bahwa sumber daya manusia berpengaruh positif dan signifikan terhadap kualitas laporan keuangan daerah. Pengelola keuangan yang memahami ilmu keuangan maka akan mudah dalam menyusun laporan keuangan. Laporan keuangan yang disusun oleh SDM yang kompeten maka laporan keuangan itu dapat dipertanggung jawabkan isinya. Proses anggaran itu sendiri yang mengidentifikasi dan memahami faktor-faktor motivasi. Proses anggaran meningkatkan kinerja individu untuk mencapai tujuan 
anggaran yang diberikan oleh organisasi melalui proses perencanaan organisasi Silva \& Jayamaha (2014).

Penelitian mengenai kinerja keuangan masih ditemukan adanya reseach gap. Karena masih belum ditemukannya hasil penelitian yang konsisten dari penelitian SDM terhadap kinerja keuangan. Penelitian dari Gomes et al., (2013) mengungkapkan bahwa adanya pengaruh positif yang signifikan dari kualitas SDM terhadap kinerja keuangan. Akan tetapi penelitian tersebut berlawanan dengan hasil penelitian dari Arifai \& Abral (2013) yang mengungkapkan bahwa tinggi rendahnya kualitas SDM tidak mempengaruhi kinerja keuangan.

Kenis (1979), Qi (2010), Silva \& Jayamaha (2014) dalam penelitiannya mengungkapkan bahwa indikator anggaran (perencanaan anggaran, pengendalian anggaran, kecanggihan anggaran, partisipasi anggaran, kejelasan sasaran anggaran, evaluasi anggaran dan kesulitan sasaran anggaran) berpengaruh positif signifikan terhadap keuangan. Sebaliknya, penelitian Bangun (2009) dan Ramandei (2009) yang mengungkapkan bahwa tidak ada hubungan yang terlalu signifikan antara kejelasan suatu sasaran anggaran terhadap kinerja dari suatu instansi pemerintah.

Pentingnya riset ini dilakukan untuk membuktikan apakah kualitas penganggaran mempengaruhi kinerja keuangan dan apakah kompetensi sumber daya manusia bidang keuangan mempengaruhi kinerja keuangan. Untuk itu peneliti mengadakan penelitian dengan judul "Pengaruh kualitas penganggaran dan kompetensi sumber daya manusia bidang keuangan terhadap kinerja keuangan sekolah".

\section{Tujuan Penelitian}

Tujuan penelitian ini adalah: (1) Menganalisis sejauh mana secara simultan kualitas penganggaran dan kompetensi sumber daya manusia bidang keuangan berpengaruh positif secara signifikan terhadap kinerja keuangan sekolah. (2) Menganalisis sejauh mana secara parsial kualitas penganggaran dan kompetensi sumber daya manusia bidang keuangan berpengaruh positif secara signifikan terhadap kinerja keuangan sekolah.

\section{Ruang Lingkup Penelitian}

Terdapat banyak faktor eksternal yang memengaruhi kinerja keuangan sekolah. Agar penelitian yang dilakukan mempunyai ruang lingkup dan arah yang jelas, maka perlu adanya pembatasan masalah yaitu kualitas penganggaran dan sumber daya manusia bidang keuangan sebagai variabel bebas, sedangkan kinerja keuangan sebagai variabel terikat. 


\section{TINJAUAN PUSTAKA DAN PERUMUSAN HIPOTESIS}

\section{Kinerja Keuangan Sekolah}

Kinerja adalah kegiatan yang dilakukan setiap individu yang berkaitan dengan pencapaian sasaran yang sudah direncanakan sebelumnya. Sedangkan kinerja menurut kamus besar bahasa indonesia adalah sesuatu yang dicapai. Berkaitan dengan hal tersebut ditemukan beberapa definisi mengenai kinerja. Sedangkan kinerja menurut Smith adalah "Output drive from processes, human or otherwise". Kinerja merupakan hasil dari suatu proses kegiatan. Deskripsi lain dari kinerja menurut Mulyasa dapat diartikan sebagai prestasi kerja, pencapaian kerja, hasil-hasil kerja atau unjuk kerja.

Kinerja merupakan suatu konsep yang bersifat universal yang merupakan efektifitas operasional seperangkat organisasi berdasarkan standar yang telah ditetapkan sebelumnya. Karena pada hakikatnya organisasi dijalankan oleh manusia maka setiap perilaku yang dilakukan oleh manusia untuk memenuhi standar yang telah ditetapkan semata-mata untuk mencapai tujua dari organisasi itu sendiri. Pengertian kinerjasama dengan prestasi kerja, yaitu perbandingan antara hasil kerja dengan standar kerja yang ditetapkan, tetapi kinerja lebih memfokuskan pada hasil kerja dari yang direncanakan.

Dari beberapa pengertian kinerja tersebut diatas dapat disimpulkan bahwa kinerja adalah prestasi kerja yang telah dicapai oleh seseorang. Kinerja merupakan hasil dari suatu aktifitas yang telah dilakukan seseorang untuk meraih suatu tujuan. Pencapaian hasil kerja ini juga sebagai bentuk perbandingan antara hasil kerja aktual dengan standar kerja.

Rohiat (2010) mendeskripsikan kinerja keuangan sebagai kegiatan yang meliputi kegiatan perencanaan, penggunaan, pencatatan data, pelaporan dan pertanggungjawaban penggunaan anggaran sesuai dengan yang direncanakan. Kinerja keuangan juga dapat diartikan sebagai tindakan pengurusan/ketatausahaan keuangan yang meliputi pencatatan, perencanaan, pelaksanaan, pertanggungjawaban, dan pelaporan.

Dari beberapa pengertian diatas bisa disimpulkan bahwa kinerja keuangan adalah suatu tindakan analisis untuk melihat sejauh mana suatu instansi dalam melaksanakan pekerjaan menggunakan aturan pelaksanaan keuangan secara baik dan benar. Kinerja keuangan sekolah yaitu penjelasan kondisi keuangan suatu sekolah yang dianalisis menggunakan alat-alat analisis keuangan, sehingga dapat diketahui tentang keadaan keuangan sekolah tersebut yang mencerminkan suatu kinerja dalam periode tertentu. Hal ini dinilai sangat penting supaya sumber daya dapat dipakai secara optimal guna menghadapi perubahan lingkungan.

Keuangan sekolah merupakan bagian yang begitu penting karena setiap kegiatan sekolah pasti membutuhkan uang. Maka dari itu, kegiatan pengelolaan keuangan sekolah perlu dilakukan dengan baik. keberhasilan sekolah dalam menyelenggarakan pendidikan yang berkualitas juga tidak terlepas dari perencanaan anggaran pendidikan yang baik serta pengalokasian dana pendidikan yang tepat sasaran. Pembiayaan pendidikan tidak hanya menyangkut analisis sumber-sumber pendapatan 
pendidikan saja, namun lebih kepada penggunaan anggaran secara efektif dan efisien. Semakin efisien anggaran yang digunakan dalam proses pendidikan, maka berkurang pula dana anggaran yang diperlukan untuk mencapai tujuannya.

Indikator kinerja keuangan menurut Rohiat (2008) meliputi kegiatan perencanaan, penggunaan, pencatatan data, pelaporan dan pertanggungjawaban penggunaan dana sesuai dengan yang direncanakan. Pengelolaan keuangan juga bisa diartikan sebagai suatu tindakan ketatausahaan yang meliputi beberapa kegiatan didalamnya.

Menurut Mardiasmo (2002) menyatakan bahwa Value for money merupakan inti pengukuran kinerja keuangan pada unit-unit kerja keuangan, dimana indikator value for money sebaiknya memusatkan perhatian pada pertanyaan mengenai ekonomis, efisiensi, dan efektifitas. Ekonomis juga sering disebut dengan perilaku hemat, hati-hati serta tidak melakukan pemborosan. Efisiensi adalah apabila suatu produk atau hasil kerja tertentu dapat tercapai dengan penggunaan sumber daya dan anggaran yang serendah-rendahnya. Sedangkan efektifitas merupakan hubungan antara keluaran dengan tujuan atau sasaran yang dicapai Mardiasmo (2002). Sedangkan menurut Fahmi (2012), menyatakan bahwa rasio keuangan sebagai alat analisis kinerja keuangan.

Indikator kinerja keuangan dalam penelitian ini meliputi penyerapan anggaran, efisiensi dan efektifitas keuangan. Hal ini didasarkan karena indikator-indikator tersebut dapat mencerminkan efisiensi biaya dan kualitas pelayanan. Disamping itu, indikator-indikator tersebut mudah dijabarkan dalam pertanyaan dalam kuisoner penelitian dibandingkan dengan indikator kinerja keuangan menurut Rohiat dan Fahmi, karena penelitian ini menggunakan data primer dengan pendekatan kuantitatif, maka yang paling tepat sebagai indikator penelitian ini adalah indikator kinerja keuangan menurut Mardiasmo. Adapun pengukurannya yaitu melalui kuisioner berupa angket yang dikumpulkan oleh tiga responden yaitu satu wakil kepala sekolah bidang keuangan dan oleh dua bendahara sekolah. Jawaban dari masing-masing responden dijumlahkan berdasarkan unit analisis. Peneliti menggunakan pendekatan penjumlahan jawaban responden bukan rata-rata karena dengan menjumlah angka yang tersaji berupa bilangan bulat atau tidak ada angka dibelakang koma. Hal ini dapat menghidari peneliti dalam kekeliruan angka karena terdapat angka dibelakang koma.

\section{Kualitas Penganggaran}

Pengertian Perencanaan menurut Nafarin (2004) yaitu menentukan sebelumnya kegiatan yang mungkin dapat dilakukan dan bagaimana melakukannya. Tujuan dari perencanaan yaitu memberikan proses umpan maju (feed forward) terhadap manajer atau pimpinan dalam pengambilan keputusan operasional. Penganggaran merupakan suatu proses menyusun anggaran dimana anggaran merupakan hasil penganggaran. Penganggaran dapat diartikan sebagai kegiatan menjelaskan, menguraikan bagaimana menghitung dan menyusun anggaran. Penganggaran menurut Nafarin yaitu suatu rencana 
keuangan dalam suatu periode yang disusun secara tertulis tentang kegiatan organisasi yang dinyatakan secara kuantitatif dan umumnya dalam satuan uang dalam periode waktu tertentu.

Kualitas penganggaran dipercaya dapat mempengaruhi kinerja keuangan, hal ini diperkuat dengan adanya teori stewardship. Teori stewardship yang berisi penggambaran kondisi manajer yang termotivasi dari target hasil utama kepentingan organisasi bukan termotivasi terhadap kepentingan pribadinya dipelopori oleh Davis et al., (1989). Teori stewardship digunakan dalam sekolah untuk memberikan gambaran situasi dimana pihak yang bersangkutan lebih mengutamakan tujuan utama yang akan dicapai oleh sekolah. Kepuasan dan kesuksesan organisasi menunjukan hubungan yang erat dalam teori tersebut. Kesuksesan organisasi menggambarkan maksimalisasi utilitas kelompok principals dan manajemen.

Kondisi sekarang yang menunjukkan semakin kompleks dengan bertambahnya tuntutan akan akuntabilitas pada organisasi sektor publik tidak terkecuali sekolah, maka principal semakin sulit untuk melaksanakan sendiri fungsi-fungsi pengelolaan. Pemisahan antara fungsi kepemilikan pada masyarakat dengan fungsi pengelolaan pada pemerintah menjadi semakin nyata. Berbagai keterbatasan, pemilik sumber daya (capital suppliers/principals) mempercayakan (trust/amanah) pengelolaan sumber daya tersebut kepada pihak lain (steward/manajemen) yang lebih capable dan siap. Hubungan antara stewards dan principals yaitu atas dasar kepercayaan (amanah/ trust), hubungan ini bertindak kolektif sesuai dengan tujuan organisasi, sehingga model yang sesuai pada kasus organisasi sektor publik atau sekolah adalah stewardship theory.

Teori stewardship berimplikasi terhadap penelitian ini yaitu untuk menjelaskan eksistensi instansi sekolah sebagai suatu lembaga sektor publik yang dapat dipercaya untuk bertindak sesuai dengan kepentingan publik dengan melaksanakan tugas dan fungsinya dengan tepat, membuat pertanggungjawaban keuangan yang diamanahkan kepadanya, sehingga tujuan sekolah, pelayanan publik maupun kesejahteraan masyarakat dapat tercapai secara maksimal. Untuk melaksanakan tanggungjawab tersebut maka stewards mengarahkan semua sumber dayanya dalam mengefektifkan pengendalian intern untuk dapat menghasilkan laporan informasi keuangan yang berkualitasdan handal. Informasi keuangan dilihat dari kinerja keuangan sekolah melalui anggaran sekolah. Anggaran yang dilakukan sekolah sendiri di lihat dari keadaan tingkat kemandirian keuangan instansi.

Partisipasi pada dasarnya merupakan proses organisasional, dimana individu terlibat dan mempunyai pengaruh secara langsung terhadap organisasi tersebut. Dalam konteks partisipasi dalam penyusunan anggaran menurut Brownell (1982) yaitu suatu proses dimana individu terlibat didalamnya mempunyai pengaruh terhadap penyusunan target angaran, yang kinerjanya dapat dievaluasi dan kemungkinan akan dihargai atas dasar pencapaian target anggaran mereka. Selain itu, pengertian partisipasi dipertegas oleh Kennis adalah suatu tingkat keikutsertaan pimpinan pada tingkat menengah dan bawah dalam menyusun suatu anggaran organisasi. Mereka sering terlibat dalam menentukan tujuan organisasi, juga aspek lain dari anggaran. Hal ini karena mereka biasanya sangat 
mengetahui operasi yang sedang dianggarkan organisasi atau karena manajemen tingkat atas ingin mendapatkan keuntungan dari partisipasi bawahan mereka.

Partisipasi dalam penyusunan anggaran di sekolah membuat para pelaksana anggaran lebih memahami masalah-masalah yang mungkin timbul pada saat pelaksanaan anggaran, sehingga partisipasi dalam penyusunan anggaran dapat meningkatkan efisiensi. Dengan partisipasi memungkinkan para pelaksana anggaran dapat berkomunikasi, berinteraksi, sehingga dengan mudah dapat meningkatkan kerjasama untuk mencapai tujuan sekolah.

Kualitas penganggaran mempengaruhi kinerja keuangan juga diperkuat oleh teori partisipasi anggaran. Anggaran yang disusun secara partisipatif diharapkan kinerja keuangan di sekolah tersebut dapat meningkat. Hal ini didasarkan pada pemikiran bahwa ketika suatu tujuan atau standar yang dirancang secara partisipatif disetujui maka Kepala sekolah, guru dan karyawan dapat bersungguhsungguh dalam tujuan atau standar tersebut yang sudah ditetapkan bersama, dan karyawan juga memiliki rasa tanggung jawab untuk mencapainya bahwa partisipasi anggaran dapat meningkatkan kualitas anggaran yang dibuat dan berdampak positif terhadap kinerja bawahan dalam menyumbangkan masukan penyusunan anggaran organisasi.

Indikator kualitas penganggaran yaitu Partisipasi dalam penyusunan Anggaran, Kejelasan, Kualitas Anggaran, Umpan Balik Anggaran, Evaluasi Anggaran, Tingkat Kesulitan Anggaran (Silva \& Jayamaha, 2014). Adapun indikator penganggaran adalah otorisasi oleh legislatif, komprehensif, keutuhan anggaran, nondiscretionary appropriation, periodik, akurat, jelas dan diketahui publik.

Indikator dalam penelitian ini menggunakan indikator dari Silva dan Jayamaha yang terdiri dari Partisipasi dalam penyusunan anggaran, kejelasan, kualitas anggaran, umpan balik anggaran, evaluasi anggaran serta tingkat kesulitan Anggaran. Hal ini didasarkan karena indikator-indikator tersebut mudah dijabarkan dalam pertanyaan dalam kuisoner penelitian dibandingkan dengan indikator kinerja keuangan. Selain itu, karena penelitian ini menggunakan data primer dengan pendekatan kuantitatif.

Pengukuran responden yaitu melalui kuisioner berupa angket yang dikumpulkan oleh tiga responden yaitu satu wakil kepala sekolah bidang keuangan dan oleh dua bendahara sekolah. Jawaban dari masing-masing responden dijumlah berdasarkan unit sekolah. Peneliti menggunakan pendekatan penjumlahan jawaban responden bukan rata-rata karena dengan menjumlah, angka yag tersaji tidak ada angka dibelakang koma. Hal ini dapat menghidari peneliti dalam kekeliruan angka karena terdapat angka dibelakang koma.

\section{Kompetensi Sumber Daya Manusia Bidang Keuangan}

Sumber Daya Manusia (SDM) bidang keuangan yaitu pihak yang terkait langsung dengan keuangan suatu organisasi baik dalam mencatat, mengelola, ataupun menghasilkan laporan keuangan organisasi. Adapun kualitas yang harus dimiliki oleh SDM bidang keuangan dalam melaksanakan tugas 
dan fungsinya yaitu dengan mengacu kepada standar kualitas lulusan akuntansi yang ditetapkan oleh IFAC (International Federation of Accountants).

Dalam pengelolaan keuangan yang baik, sekolah tersebut harus memiliki sumber daya manusia yang kompeten. Sumber daya yang kompeten ditunjukkan dengan latar belakang pendidikan akuntansi, sering mengikuti pendidikan dan pelatihan dan mempunyai pengalaman kerja dibidang keuangan (Gomes et al., 2013; Wansyah et al., 2012).

Resources-based theory (RBT) atau dikenal juga dengan teori berbasis sumber daya menggunakan pendekatan berbasis sumber daya dalam menganalisis keunggulan pesaingnya. Resources-based theory merupakan suatu pemikiran yang berkembang dalam manajemen strategik dan keunggulan kompetitif sekolah yang menganalisis dan menginterpretasikan sumber daya organisasi untuk memahami bagaimana organisasi mencapai keunggulan kompetitif berkelanjutan. Resourcesbased theory dipelopori oleh Penrose. Penrose mengemukakan bahwa sumber daya perusahaan adalah heterogen. Jasa produktif yang tersedia berasal dari sumber daya perusahaan yang memberikan karakter unik bagi tiap-tiap perusahaan dalam menjalankan operasionalnya.

Kompetensi sumber daya manusia mempengaruhi kinerja keuangan sekolah, hal ini berdasarkan Resources-based theory menggunakan pendekatan berbasis sumber daya. Resources-based theory merupakan suatu pemikiran yang berkembang dalam manajemen strategik dan keunggulan kompetitif perusahaan yang menganalisis dan menginterpretasikan sumber daya organisasi untuk memahami bagaimana organisasi mencapai keunggulan kompetitif berkelanjutan (Hadi Muttaqin, 2013). Pandangan Hadi Muttaqin berdasarkan konsep RBT, mengemukakan jika perusahaan mampu mengelola sumber daya secara efektif maka akan dapat menciptakan keunggulan kompetitif dibanding para pesaing. Sumber daya manusia yang memiliki keterampilan dan kompetensi tinggi merupakan keunggulan kompetitif bagi sekolah apabila dapat dimanfaatkan dan mengelola potensi yang dimiliki karyawan dengan baik, maka hal ini dapat meningkatkan produktivitas karyawan. Dengan adanya peningkatan produktivitas, maka kinerja perusahaan dapat meningkat dan dengan adanya pengelolaan sumber daya yang efektif tersebut maka pemakaian sumber daya atau pengeluaran dapat lebih efektif dan efisien.

Menurut Ulum (2009), Resources-based theory menyatakan bahwa perusahaan memiliki sumber daya yang dapat menjadikan keunggulan bagi perusahaan dalam bersaing dan mampu mengarahkan perusahaan untuk memiliki kinerja jangka panjang yang baik. Sumber daya yang berharga dan langka dapat diarahkan untuk menciptakan keunggulan bersaing, sehingga resources yang dimiliki mampu bertahan lama dan tidak mudah ditiru, ditransfer atau digantikan oleh pesaingnya.

Dalam konteks untuk menjelaskan pengaruh kompetensi sumber daya manusia pengelola keuangan terhadap kinerja keuangan sekolah, bahwa menurut pandangan bahwa sekolah memperoleh keunggulan kompetitif dan kinerja keuangan yang baik dengan cara memiliki, menguasai, dan 
memanfaatkan aset-aset strategis yang penting, termasuk aset berwujud maupun aset tidak berwujud. Asset tersebut berupa sumber daya manusia bidang keuangan.

Berdasarkan konsep Resources-based theory, jika sekolah mampu mengelola sumber daya secara efektif maka dapat menciptakan keunggulan kompetitif dibanding para pesaing. Sumber daya manusia yang memiliki keterampilan dan kompetensi tinggi merupakan keunggulan kompetitif bagi sekolah.

Teori keagenan menyatakan bahwa organisasi yang memisahkan fungsi pengelolaan dan kepemilikan dapat mempengaruhi terhadap konflik keagenan Jensen \& Meckling, (1976). Teori ini menekankan bahwa perencanaan pengukuran prestasi dan imbalan yang diberikan agar para pimpinan berperilaku positif yang menguntungkan perusahaan secara keseluruhan. Eko Raharjo menambahkan hal penting dalam teori agensi ini, yaitu kewenangan yang diberikan kepada agen untuk melakukan suatu tindakan dalam hal kepentingan pemilik.

Kompetensi sumber daya manusia bidang keuangan mempengaruhi kinerja keuangan sekolah berdasarkan teori keagenan. Teori ini menjelaskan bahwa hubungan agensi muncul ketika satu orang atau lebih (principal) mempekerjakan orang lain untuk memberikan jasa dan kemudian memberikan wewenang kepada agent tersebut dalam mengambil keputusan. Salah satu agent dalam sekolah dapat berupa Bendahara sekolah. Adanya ketidakseimbangan penguasaan informasi dapat memicu munculnya kondisi yang disebut sebagai asimetri informasi. Dengan adanya asimetri informasi antara manajemen dengan pemilik dapat memberi kesempatan kepada bendahara untuk melakukan pembuatan laporan keuangan sekolah yang baik sehingga dapat meningkatkan kinerja keuangan sekolah.

Indikator kompetensi sumber daya manusia bidang keuangan yaitu terdiri dari latar belakang pendidikan, pendidikan dan pelatihan serta pengalaman bekerja (Gomes et al., 2013; Wansyah et al., 2012). Hal ini didasarkan karena indikator-indikator tersebut dapat mencerminkan skill, knowledge dan attitude sumber daya manusia bidang keuangan. Disamping itu, indikator-indikator tersebut mudah dijabarkan dalam pertanyaan dalam kuisoner penelitian dibandingkan dengan indikator menurut IFAC (International Federation of Accountants). Dalam penelitian ini, sumber daya manusia bidang keuangan belum pasti lulusan dari akuntansi sedangkan indikator menurut IFAC adalah indikator untuk mengukur kompetensi sumber daya manusia lulusan akuntansi. Adapun pengukurannya yaitu melalui kuisioner berupa angket yang dikumpulkan oleh tiga responden yaitu satu wakil kepala sekolah bidang keuangan dan oleh dua bendahara sekolah. Jawaban dari masing-masing responden dijumlah berdasarkan unit analisis. Peneliti menggunakan pendekatan penjumlahan jawaban responden bukan rata-rata karena dengan menjumlah, angka yag tersaji tidak ada angka dibelakang koma. Hal ini dapat menghidari peneliti dalam kekeliruan angka karena terdapat angka dibelakang koma. 


\section{PENGEMBANGAN HIPOTESIS}

\section{Pengaruh Kualitas Penganggaran Terhadap Kinerja Keuangan Sekolah}

Kualitas penganggaran mempengaruhi kinerja keuangan sekolah. Hal ini sejalan dengan yang dikemukakan oleh Mardiasmo, (2002), Anggaran merupakan managerial plan for action untuk mendukung tercapainya tujuan organisasi dengan memperhatikan aspek-aspek yang harus tercakup dalam anggaran sektor publik yaitu: (1) Aspek Perencanaan; (2) Aspek Pengendalian; dan (3) Aspek Akuntabilitas. Dalam aspek perencanaan perlu adanya koordinasi yang baik dalam proses penyusunan anggaran, dimana menurut Lewis (1999) proses penyusunan anggaran ini disebut penganggaran. Penganggaran yang baik dalam suatu instansi dapat memberikan dasar bagi penggunaan anggaran dan menghasilkan kinerja keuangan yang valid dan akurat.

Pendapat di atas didukung oleh hasil penelitian yang dilakukan oleh Riawan (2016) yang mengungkapkan bahwa kualitas penganggaran berpengaruh positif signifikan terhadap kinerja keuangan daerah. Diperkuat oleh hasil penelitian Kenis (1979), Qi (2010), Silva \& Jayamaha (2014) yang menunjukkan karakteristik anggaran (perencanaan anggaran, pengendalian anggaran, kecanggihan anggaran, partisipasi anggaran, kejelasan sasaran anggaran, evaluasi anggaran dan kesulitan sasaran anggaran) berpengaruh positif signifikan terhadap kinerja keuangan

Menurut pandangan Resources-based theory (RBT) sekolah yang memiliki sumber daya yang kompeten berupa kualitas penganggaran, maka dapat meningkatkan kinerja sekolah. Resources-based theory (RBT) berfokus pada konsep atribut sekolah yang sulit untuk ditiru oleh kompetitor lain karena bersifat heterogen maka performa antara sekolah satu dengan yang lain berbeda, dan dengan pengelolaan sumber daya secara tepat diharapkan mampu menciptakan keunggulan kompetitif serta memberikan nilai lebih dibandingkan dengan kompetitor sejenis.

Pertimbangan teori dan logika di atas, maka kualitas penganggaran yang baik dapat memberikan pengaruh terhadap kinerja keuangan sekolah. Hal ini meyakinkan peneliti dalam memberikan hipotesis penelitian bahwa kualitas penganggaran berpengaruh positif terhadap kinerja keuangan sekolah.

H1 : Kualitas penganggaran berpengaruh secara positif tehadap kinerja keuangan sekolah

\section{Pengaruh Kompetensi Sumber Daya Manusia Bidang Keuangan Terhadap Kinerja Keuangan Sekolah}

Kinerja keuangan sekolah dipengaruhi oleh kompetensi sumber daya manusia bidang keuangan. Pengelola keuangan yang memahami ilmu keuangan maka dapat mempermudah dalam menyusun laporan keuangan. Laporan keuangan yang disusun oleh SDM yang kompeten maka laporan keuangan itu dapat dipertanggung jawabkan isinya. Kompetensi sumber daya manusia bidang keuangan sangat mempengaruhi kinerja keuangan sekolah didasarkan pada teori Resources-based theory (RBT). Dengan 
sumber daya yang unggul dalam hal ini kompetensi SDM bidang keuangan yang baik diharapkan sekolah mampu melakukan strategi bisnis yang baik, yang pada akhirnya membawa sekolah mempermudah dalam mengelola kinerja keuangan sekolah. Penelitian yang menunjukkan pengaruh langsung antara sumber daya manusia terhadap kinerja keuangan yang dilakukan oleh Wati et al., (2014) yang mengungkapkan bahwa sumber daya manusia berpengaruh positif dan signifikan terhadap kualitas laporan keuangan daerah. Pertimbangan teori dan logika di atas, maka Kompetensi sumber daya manusia bidang keuangan yang baik dapat memberikan pengaruh dalam mengelola kinerja keuangan sekolah. Hal ini meyakinkan peneliti dalam memberikan hipotesis penelitian bahwa kompetensi sumber daya manusia bidang keuangan berpengaruh positif terhadap kinerja keuangan sekolah.

H2 : Kompetensi sumber daya manusia bidang keuangan berpengaruh secara positif tehadap kinerja keuangan sekolah

\section{METODE PENELITIAN}

Pendekatan penelitian ini menggunakan pendekatan kuantitatif. Populasi dalam penelitian ini adalah. Populasi dalam penelitian ini adalah seluruh SMK se-Kabupaten Pemalang yang berjumlah 42 SMK. Sumber data penelitian ini menggunakan kuesioner, Penelitian menggunakan analisis deskriptif dan melakukan uji asumsi klasik serta menggunakan analisis uji selisih mutlak Hasil uji normalitas dengan perhitungan kolmogorof-smirnof didapatkan nilai signifikansi diatas 0,05. Hal ini berarti bahwa data residual berdistribusi normal. Hasil uji multikolonieritas dalam penelitian ini memiliki nilai toleransinya $\geq 0.10$ dan nilai VIF masing-masing variabel bebas $\leq 10$, maka tidak mengandung multikolonieritas dan model regresi tidak mengandung heterokedastisitas.

\section{HASIL DAN PEMBAHASAN}

Untuk memperkuat hasil analisis, penulis menggunakan tabel hitung regresi berganda. Hasil penelitian ini dapat ditunjukan dengan tabel berikut:

Tabel 1 Hasil Analisis Regresi Berganda I dengan Kinerja Keuangan sebagai dan Variabel Terikat

\begin{tabular}{|l|c|c|c|c|c|}
\hline \multicolumn{1}{|c|}{ Variabel } & $\begin{array}{c}\text { Stand. } \\
\text { Coeffisien } \\
\text { ts Beta }\end{array}$ & $\begin{array}{c}\text { t } \\
\text { Hitung }\end{array}$ & Sig. & $\begin{array}{c}\text { R } \\
\text { Square }\end{array}$ & $\begin{array}{c}\text { Adj. R } \\
\text { Square }\end{array}$ \\
\hline $\begin{array}{l}\text { Kualitas Penganggaran (X1) } \\
\text { Kompetensi SDM bidang } \\
\text { Keuangan (X2) }\end{array}$ & 5,041 & 3,341 & 0,002 & 0,545 & 0,472 \\
\hline
\end{tabular}

Sumber: Data Primer diolah (2020)

Sehingga didapat persamaan regresi:

$$
Y=181,195+5,041 X_{1}+4,303 X_{2}
$$




\section{Pengaruh Kualitas Penganggaran Terhadap Kinerja Keuangan sekolah}

Hasil penelitian menunjukkan pengujian hipotesis penelitian pertama (H1) yang menyebutkan kualitas penganggaran berpengaruh secara positif tehadap kinerja keuangan sekolah secara signifikan dapat diterima. Hal ini memberikan bukti secara empiris bahwa kualitas penganggaran berpengaruh positif terhadap kinerja keuangan sekolah.

Berdasarkan hasil penelitian diketahui rata-rata kualitas penganggaran sekolah menengah kejuruan di Kabupaten Pemalang bahwa rata-rata kualitas penganggaran sekolah rata-rata (Mean) dengan prosentase $79,08 \%$ dengan nilai maksimum sebanyak $91 \%$ dan nilai minimum sebesar 70\% dengan nilai deviasi standar sebesar 5,12\%. Hasil ini menunjukkan bahwa pada umumnya kualitas penganggaran baik sekolah menengah kejuruan negri maupun swasta di Kaupaten Pemalang sudah dikelola dengan baik yakni mencapai 79\%. Berarti hampir seluruh SMK di Kabupaten pemalang sudah berusaha menerapkan partisipasi dalam penyusunan anggaran, kejelasan tujuan anggaran, umpa balik anggaran, evaluasi anggaran dan tingkat kesuitan anggaran,

Koefisien regresi X1 (kualitas penganggaran) mempunyai tingkat signifikan sebesar 0,002 dan nilai koefisien regresi 1 sebesar 5,041. Hal ini berarti kualitas penganggaran berpengaruh positif terhadap kinerja keuangan, dan setiap ada kenaikan satu poin kualitas penganggaran sementara variabel lain dianggap tetap maka akan diikuti dengan kenaikan kinerja keuangan sebesar 5,041.

Hasil penelitian ini mengindikasikan bahwa tinggi dan rendahnya kualitas penganggaran suatu organisasi akan mempengaruhi tinggi rendahnya kinerja keuangan. Hal ini menunjukan bahwa semakin tinggi kualitas anggaran (Partisipasi dalam penyusunan anggaran, kejelasan sasaran anggaran, umpan balik anggaran, evaluasi anggaran dan tingkat kesulitan anggaran) maka akan tercapai kinerja keuangan yang baik. Dengan demikian, yang harus dilakukan oleh setiap jajaran manajemen sekolah adalah memaksimalkan kualitas penganggaran melalui perencanaan anggaran yang baik, menggambarkan sasaran anggaran yang jelas agar dimengerti oleh yang bertanggung jawab atas pencapaian sasaran anggaran tersebut, serta melakukan evaluasi agar tidak terjadi penyimpangan anggaran organisasi.

Kualitas penganggaran mempengaruhi kinerja keuangan sekolah. Hal ini sejalan dengan yang dikemukakan oleh Mardiasmo, (2002), Anggaran merupakan managerial plan for action untuk mendukung tercapainya tujuan organisasi dengan memperhatikan aspek-aspek yang harus tercakup dalam anggaran sektor publik yaitu: (1) Aspek Perencanaan; (2) Aspek Pengendalian; dan (3) Aspek Akuntabilitas. Dalam aspek perencanaan perlu adanya koordinasi yang baik dalam proses penyusunan anggaran. Proses penyusunan anggaran ini disebut penganggaran. Penganggaran yang baik dalam suatu instansi dapat memberikan dasar bagi penggunaan anggaran dan menghasilkan kualitas laporan keuangan yang valid dan akurat.

Hasil penelitian ini juga sejalan dengan hasil penelitian yang dilakukan oleh Riawan (2016) yang menyatakan bahwa kualitas penganggaran berpengaruh positif signifikan terhadap kinerja keuangan daerah. Hasil penelitian ini juga sesuai dengan teori Resources-based theory (RBT). Dimana sekolah yang 
memiliki sumber daya manusia yang kompeten berupa kualitas penganggaran, maka akan meningkatkan kinerja sekolah. Resources-based theory (RBT) berfokus pada konsep atribut sekolahyang sulit untuk ditiru oleh kompetitor lain karena bersifat heterogen maka performa antara sekolah satu dengan yang lain tidak sama, dan dengan pengelolaan sumber daya secara tepat diharapkan mampu menciptakan keunggulan kompetitif serta memberikan nilai lebih dibandingkan dengan kompetitor sejenis.

\section{Pengaruh Kompetensi Sumber Daya Manusia Bidang Keuangan Terhadap Kinerja Keuangan sekolah}

Berdasarkan hasil penelitian menunjukkan pengujian hipotesis penelitian kedua (H2) yang menyebutkan sumber daya manusia bidang keuangan berpengaruh secara positif tehadap kinerja keuangan sekolah secara signifikan dapat diterima. Hal ini memberikan bukti secara empiris bahwa sumber daya manusia bidang keuangan berpengaruh positif terhadap kinerja keuangan sekolah.

Berdasarkan hasil penelitian diketahui rata-rata sumber daya manusia bidang keuangan sekolah menengah kejuruan di Kabupaten Pemalang dengan prosentase dengan prosentase 86,10\% dengan nilai maksimum sebanyak $94 \%$ dan nilai minimum sebesar $74 \%$ dengan nilai deviasi standar sebesar 4,18\%. Hasil ini menunjukkan bahwa pada umumnya kompetensi sumber daya manusia bidang keuangan baik sekolah menengah kejuruan negeri maupun swasta di Kabupaten Pemalang sudah baik yakni mencapai $86,10 \%$. Berarti hampir seluruh sumber daya manusia bidang keuangan SMK di Kabupaten pemalang sudah memiliki latar pendidikan yang baik berkaitan dengan profesinya, sudah mengikuti pendidikan dan pelatihan serta sudah berpengalaman.

Koefisien regresi X2 (sumber daya manusia bidang keuangan) mempunyai tingkat signifikan sebesar 0,043 dan nilai koefisien regresi 1 sebesar 4,303. Hal ini berarti sumber daya manusia bidang keuangan mempengaruhi kinerja keuangan dan setiap ada kenaikan satu poin sumber daya manusia bidang keuangan sementara variabel lain dianggap tetap maka akan diikuti dengan kenaikan kinerja keuangan sebesar 4,303.

Kompetensi sumber daya manusia bidang keuangan sangat mempengaruhi kinerja keuangan sekolah didasarkan pada teori Resources-based theory (RBT). Teori ini merupakan suatu pemikiran yang berkembang dalam teori manajemen stratejik dan keunggulan kompetitif perusahaan menyakini bahwa perusahaanakan mencapai keunggulan jika memiliki sumber daya yang unggul. Dengan sumber daya yang unggul dalam hal ini budaya organisasi yang baik diharapkan sekolah dapat melakukan strategi bisnis yang pada akhirnya membawa sekolah mempermudah dalam mengelola kinerja keuangan sekolah. Hal ini sesuai dengan hasil penelitian Desiana Wati, dkk (2014) yang menyatakan bahwa sumber daya manusia berpengaruh positif dan signifikan terhadap kualitas laporan keuangan daerah 


\section{KESIMPULAN}

Hasil penelitian dan pembahasan dapat ditarik kesimpulan sebagai berikut: (1) Terdapat pengaruh positif secara signifikan kualitas penganggaran terhadap kinerja keuangan sekolah. Hal ini berarti bahwa semakin tingggi kualitas penganggaran maka semakin tinggi pengaruhnya terhadap kinerja keuangan. (2) Terdapat pengaruh positif secara signifikan kompetensi sumber daya manusia bidang keuangan terhadap kinerja keuangan sekolah. Hal ini berarti bahwa semakin tingggi kompetensi sumber daya manusia bidang keuangan maka semakin tinggi pengaruhnya terhadap kinerja keuangan.

\section{DAFTAR PUSTAKA}

Arifai, M., \& Abral, E. (2013). FAKTOR YANG MEMPENGARUHI IMPLEMENTASI KINERJA KEUANGAN PEMERINTAH DAERAH. Journal of Chemical Information and Modeling, 53(9), 1689-1699. https://doi.org/10.1017/CB09781107415324.004

Bangun, A. (2009). Pengaruh Partisipasi dalam Penyusunan Anggaran, Kejelasan Sasaran Anggaran dan Struktur Desentralisasi Terhadap Kinerja Manajerial SKPD dengan Pengawasan Internal Sebagai Variabel Pemoderasi (Studi Kasus pada Pemerintah Kabupaten Deli Serdang. In Tesis.

Brownell, P. (1982). A Field Study Examination of Budgetary Participation and Locus of Control. ALFRED P. SLOAN SCHOOL OF MANAGEMENT. https://doi.org/10.1017/CB09781107415324.004

Davis, F. D., Bagozzi, R. P., \& Warshaw, P. R. (1989). User Acceptance of Computer Technology: A Comparison of Two Theoretical Models. Management Science, 35(8), 982-1003. https://doi.org/10.1287/mnsc.35.8.982

Fahmi, I. (2012). Analisis Kinerja Keuangan Panduan bagi Akademisi, Manajer, dan Investor untuk Menilai dan Menganalisis Bisnis dari ASpek Keuangan. In CV ALFABETA.

Gomes, R. C., Alfinito, S., \& Albuquerque, P. H. M. (2013). Analyzing local government financial performance: evidence from Brazilian municipalities 2005-2008. Revista de Administração Contemporânea, 17(6), 704-719. https://doi.org/10.1590/s1415-65552013000600005

Jensen, M. C., \& Meckling, W. H. (1976). Theory of the firm: Managerial behavior, agency costs and ownership structure. Journal of Financial Economics. https://doi.org/10.1016/0304405X(76)90026-X

Lewis, R. (1999). Managing To Achieve a Vision. British Journal of Educational Technology, 30(2), 141150.

Mardiasmo. (2002). Akuntansi Sektor Publik. Yogyakarta: Andi.

Ramandei, P. (2009). Pengaruh Karakteristik Sasaran Anggaran dan Sistem Pengendalian Intern terhadap Kinerja Manajerial Aparat Pemerintah Daerah. Tesis, 1-16. http://eprints.undip.ac.id/7895/

Riawan. (2016). Pengaruh Kualitas Sumber Daya Manusia dan Kualitas Anggaran Terhadap Kinerja Keuangan Daerah Yang Dimoderasi Dengan SIMDA Pada SKPD Kabupaten Buton Utara. 8(1), 5060 .

Silva, L. M. D., \& Jayamaha, A. (2014). Budgetary Process and Organizational Performance of Apparel Industry in Sri Lanka Budgetary Process and Organizational Performance of Apparel Industry in Sri Lanka. Journal of Emerging Trends in Economics and Management Sciences (JETEMS), 3(May), 354-360.

Ulum, I. (2009). Intellectual Capital : Konsep dan Kajian Empiris (Intellectual Capital : Concept and Empirical Study). In Jurnal Inferensi. 
Ulumudin, I. (2014). Evaluasi Kinerja Keuangan Daerah Se Karesidenan Pekalongan Tahun 2007-2011. 34-45. http://eprints.ums.ac.id/32068/

Wansyah, H., Darmawis, \& Bakar, U. (2012). Pengaruh Kapasitas Sumber Daya Manusia, Pemanfaatan Teknologi Informasi dan Kegiatan Pengendalian terhadap Nilai Informasi Pelaporan Keuangan SKPD pada Provinsi Aceh. Jurnal Akuntansi Pascasarjana Universitas Syiah Kuala, 1(1), 43-58.

Wati, K. D., Herawati, N. T., \& Sinarwati, N. K. (2014). Pengaruh kompetensi sdm, penerapan sap, dan sistem akuntansi keuangan daerah terhadap kualitas laporan keuangan daerah. E-Journal S1 Ak Universitas Pendidikan Ganesha, 2(1).

Widodo, J. (2014). - Seminar Nasional Evaluasi Pendidikan Tahun 2014 —. Jurnal Indonesia. https://doi.org/10.1017/CB09781107415324.004 